\title{
Nonclinical Study Sponsor Name
}

National Cancer Institute

\section{Source}

National Cancer Institute. Nonclinical Study Sponsor Name. NCI Thesaurus. Code C129946.

The name of the entity that is responsible for the initiation, management, and/or financing of a nonclinical study. $(\mathrm{NCl})$ 